\title{
Imperial Drug Economies, Development, and the Search for Alternatives in Asia, from Colonialism to Decolonisation
}

\author{
John Collins
}

\begin{abstract}
This chapter challenges contemporary policy conceptions on the historical relationship between drugs and development policies. It uses a historical analysis to examine the interaction of drugs, governance, security, welfare and economic development policies within drug producing contexts in Asia, from colonialism through the period of decolonisation. It highlights that although modern narratives of drugs and development tend to view the latter as new and involving even immediately contemporary innovations for dealing with the outcomes of drug economies and drug policies, the historical reality is much more complex. Managing drugs and development was a fundamental historical process of state regulation, control and the settling of geographical boundaries, both economically and physically. This chapter posits two foundational ideas. First, the issues of drugs and development have always been fundamentally linked, from the globalisation of trade through mercantilist imperial policies, state formation, the limits of governance, the distribution of economic gains, and political economy outcomes stretching from the local to the global. Drugs, licit and illicit, have therefore always been an issue of economic development. Second, policymakers have long recognised and developed state responses based on the above reality. While not going under its now 'official' title, many of the principles of 'alternative development' have been ingrained in policy responses and limitations over the past several centuries.
\end{abstract}

\section{Introduction}

Modern narratives of drugs and development tend to view the latter as new and even immediately contemporary innovations for dealing with the outcomes of drug economies and drug policies (UN General Assembly, 2013). Alternative development is seen as a logical evolution of the United Nations (UN) drug control system, rather than a phenomenon whose doctrines long predated the modern control system. Moreover, attempts to link contemporary

(C) JOHN COLLINS, 2020 | DOI:10.1163/9789004440494_004

This is an open access chapter distributed under the terms of the CC-BY-NC 4.o licensenn Collins - 9789004440494 
illicit economies and their management to the Sustainable Development Goals (SDG s) again view this as a novel framework, the tenets of which policymakers have historically shunned. In both cases, the historical reality, as this chapter will demonstrate, was far more complex. Opium and the licit-illicit economy divide was always a fundamental issue of political economy and economic development. Moreover it was treated as such by local elites and European colonial elites. Its typification into a simple dichotomy between eradication and development, as often encapsulated within one-dimensional views of 'alternative development', misses this larger historical story. Drugs and development was a fundamental historical process of state regulation, control and the settling of geographical boundaries, both economically and physically. This chapter attempts to tell this story through the long history of drugs as development and the history of drug policy as development within the Asian region up to the period of decolonisation.

This paper posits two foundational ideas for better understanding contemporary drugs and development policies. First, the issues of drugs and development have always been fundamentally linked, from the globalisation of trade, through mercantilist imperial policies, state formation, the limits of governance, the distribution of economic gains, and political economy outcomes stretching from the local to the global. Drugs, licit and illicit have therefore always been an issue of economic development. Second, policymakers have long recognised and developed state responses based on the above reality. While not under the official title of 'alternative development', many of its principles have been ingrained in policy responses and limitations over the past several centuries. British administrators sought to navigate the political economy of the Indian opium trade. Administrators in Burma promoted a development-first, harm reductionist approach (although not specifically labelled as such) that placed economic and political stability ahead of ideological and drug fetishist goals of eradication and prohibitions, even if this ran counter to emerging international norms and obligations. Beneath often lofty, ideological and normative aspirational goals, policymakers frequently and explicitly recognised the issue of drugs and drug markets as one of economic development and economic fundamentals.

This of course raises the complicated and contested question of how one defines 'development', particularly over a long historical case study. For example, it might be pointed out that, Asian countries, during the colonial period, had little agency or right over national governance issues that were determined to a large extent in the capitals of Europe. This raises the question of 'whose development?' Nevertheless, to proceed with this discussion we must build a model of development based on a selection of criteria (Bassi et al., 2019). As 
this is a discussion of the role of development within drug control, we must use the two most commonly referenced frameworks-that of alternative development and how the United Nations General Assembly Special Session on the World Drug Problem in 2016 addressed this (UN General Assembly, 2016), and the 2030 Agenda for Sustainable Development agreed in 2015 (UN General Assembly, 2015). This chapter thereby engages questions of development and drug control policies from UN frameworks that serve as the basis for understanding contemporary donor and member state approaches. Furthermore, it draws on drug crop cultivation literature that utilises development paradigms to understand the 'double-edged sword' of illicit drug economies (Buxton, 2015; Mansfield and Pain, 2005). That is, that they represent an alienating force with regard to many mainstream development processes, in many ways separating the communities from the political and economic core, while also providing cash crops to enable self-sufficiency, capital accumulation, resources for paid access to private health and economic and security services. The question, therefore, is not simply one of drug crops providing short-term economic gains or 'growth'. It is instead about understanding the impacts of these changing drug economies and the regulations governing them, on the fundamental social, economic, political, environmental and security circumstances of communities and nation states experiencing them. These are, under the umbrella of the 2030 Agenda for Sustainable Development, key issues related to economic development and can be conceptualised as such in historical analyses. This is the jumping off point for this chapter.

\section{Drugs as a Historical Phenomenon}

As historian William $\mathrm{O}$. Walker III wrote, "[t]here is no adequate way $[. .$.$] to$ understand the foreign and security policy issues affecting Asia without appreciation of opium's role' (Walker, 1992). This chapter expands this statement to include the role of development: there is no way to understand the economic development and development policies of large parts of Asia without a thorough understanding of the role of drugs.

First, the globalisation of the opium trade in Asia closely resembled the globalisation of transnational labour and population flows. Beginning in the nineteenth century, China provided the first large-scale 'free wage labour' for parts of Southeast Asia. Migrant workers moved en masse into these regions - namely Malaya, Sumatra, southern Siam, Tonkin and Borneo-and were quickly recruited into tin or gold mines, or plantations of pepper, gambier, sugar, tobacco and rubber (Trocki, 2002, 300). Although Chinese migration 
had less of an impact on more populous regions, such as Siam, Java, CochinChina and Southern Burma (Trocki, 2002), the migration of Haw, Hmong and other tribes from China into other parts of Asia favoured the spread of opium cultivation and consumption (Chouvy, 2013). The two often moved hand in hand. For example, an official League of Nations Commission of Enquiry reported in 1930 that '[c]ontact with Chinese Immigrants has in other FarEastern territories usually been the cause of the indigenous population acquiring the opium-smoking habit' (League of Nations, 1930, 37). Indeed, the recognition of this interaction between commodity trades and labour movements helps explain the historical plurality of regulatory frameworks enforced within many Southeast Asian territories, with different rules applying to different migrant or indigenous communities within the same geographic territories (Collins, 2017a).

Second, the expansion of drug markets was an inevitably economic, and thereby developmental, phenomenon. The expansion of drug supply and drug markets globally was an innate process of globalisation. As Chouvy writes, '[t]he caravan tracks of the Haw, which crisscrossed Siam very early, largely contributed in turning Thailand into a privileged hub of heroin trafficking' (Chouvy, 2013, 4). Meanwhile, the contemporary trade routes serving legal and illegal commodities were effectively the same as those the Burmese had used previously to invade Siam, including in the sixteenth and eighteenth centuries (Chouvy, 2013). The link between illicit economies, empire, state formation and conflict is at once inextricable and innately complex.

Third, the production and consumption of mind-altering substances has been an inextricable part of social history. Globalisation merely accelerated and magnified this phenomenon, making it global. As David Courtwright highlights, like other global commodities drugs were influenced by technological changes that significantly increased the gross tonnage of supplies and trade. Efforts to control drugs were an inevitable by-product of their increasing prevalence, ubiquity, visibility and economic impacts (Courtwright, 2012). Global control initiatives therefore focused on regulating and restricting supply to socially determined notions of 'legitimate' use. As McAllister and Spillane write, 'The central question' at the turn of the twentieth century 'was not whether the state would ultimately restrict some aspects of distribution and sale, but whose authority would be privileged in the process of creating and implementing those regulations' (Spillane and McAllister, 2003, S.6). State interactions with drug markets, and attempts to define the limits of acceptability, desirability and the benefits/costs that accrued to governing political entities, represented a modern extension of earlier social norms and practices. The latter had served as checks on production and consumption in 
premodern societies while modern empires and states sought to control these commodities through regulations and prohibitions in pursuit of politicaleconomic ends.

\section{European Empires, Mercantilism and Control of the Sino-Indian Opium Trade}

Historian Peter Dale Scott similarly argues that in order to understand postWorld War II illicit drug trades in Asia, one must first understand the opium policies of the British Empire in the nineteenth century (Scott, 2010). The SinoIndian opium trade began in the mid-sixteenth century, and was soon taken over by Portuguese, British and Dutch traders. A fragmentary and ultimately localised trade soon became subsumed under the monopoly of the British East India Trading Company (EIC). With it, India became the dominant regional, and thereby global actor in the trade (Windle, 2012). Thus, European empires transformed the issue into a global one, with concomitant cross border geopolitical and legal issues. Where one imperial state, China, increasingly sought to restrict and prohibit the domestic consumption of opium (Westad, 2012), European empires looked to it as a corrective to major trading imbalances and thereby a mercantilist route towards trading and political power within the region (Trocki, 1999).

China's early opium concerns became acute as it manifested as a foreign influence. The prohibitionist policies of 1729 directly reflected its perception as a practice centred on the south-east coast. Opium, under this conception, was not a problem related to cultivation or consumption but to smuggling and foreign interference (Bello, 2003). As opium became associated with Western consumption practices, namely the mixing with tobacco to form smokable opium known as 'madak', so too did the sense of foreign incursion and threat (Courtwright, 2012). These early concerns became amplified when it became apparent that the Chinese state was haemorrhaging silver to buy Indian opium. Qing efforts to counter these outflows ultimately produced the Opium Wars with Great Britain (Bello, 2003). China's defeat in these conflicts, and its forced opening to trade with the West, saw China legalise opium. This was formalised under the Convention of Peking of 1860, in part to provide revenues to sustain the ever-weakening Chinese government (Brown, 2002).

Meanwhile, at a more local level, the development of Yunnan as a major source of opium reiterated both the formidable economic role of the commodity as well as the limits of the Qing State's reach. As Bello writes, 
Qing prohibition in the southwest alerted authorities to the existence of an alternative domestic source of opium that thrived on weaknesses in the imperial administrative system. Ethno-geographic conditions in Yunnan weakened the central government's local administrative presence, which was already prone to a dependence on unconventional revenue sources. The southwestern traffic was well placed to exploit these weaknesses. Moreover, local cultivation of opium proved particularly suited to the needs of the indigenous peoples, Han peasants, and merchants, as well as local dynastic officials, because it was powerful enough to generate incomes for all concerned.

BELLO, 2003, 1134

Meanwhile, the Qing State itself became reliant on opium revenue, a reality that helped negate central government efforts to enforce prohibition in many interior regions (Bello, 2003, 1135). Indeed, Bello continues, 'it was competition from southwestern afurong, not pressure from central government prohibition, [that] ultimately drove Indian opium from China' (Bello, 2003, 1134).

The development of opium markets in Asia thereby had undoubtedly large macroeconomic and thus political impacts. These often simply reinforced economic development processes already underway. European powers used revenue farming systems to minimise their imperial administrative and political cost base. In this way, they 'farmed out' revenue collection to indigenous elites by auctioning the right to tax or develop a monopoly on distribution or sale of a specific good, including opium, alcohol, sex work, gambling and other activities. Opium represented a particularly liquid enterprise with high cash flow and thereby an ability to accumulate large capital stocks. Trocki goes further, arguing that the opium farming systems existing in parts of India, China and virtually all Southeast Asian states 'were important adjuncts of capitalist development within the region' (Trocki, 2002, 297). Therein developed a premodern economic fabric to weave together the complex strands of governance, taxation, local elite development and control of the most fundamental principle of sovereignty - the ability to tax. Again, as Trocki writes,

The farms also financed commodity production and helped to generate the infrastructure for consumer economies. These institutions helped to create the finance and state structures that protected businessmen and their profits [...] In fact, all Asian governments depended upon opium farms for major portions of their revenue.

TROCKI, 2002, pp. 297-8 
There seems little to question, therefore, regarding the common belief that opium held 'immense importance' for the Indian and global economy in the nineteenth century (Richards, 2002a, 151). For all its merits, however, Trocki's work derives from a heavily critical framework, perhaps too deterministic in its utilisation of macroeconomic indicators to demonstrate an imperial inflection point in Asian economic development. This may help overshadow the situational role of opium within local political economies. Taking the latter approach may instead place imperialism as one strand in a broader web of development. Furthermore, Trocki's work perhaps serves to fetishise opium as a sole determinant of imperial expansion. Extending Trocki's macroeconomic insights, a microeconomic level analysis provides some additional potentially useful insights.

Kranton and Swamy examine the market structures surrounding the EIC opium monopoly and compare it to its textiles trade (Kranton and Swamy, 2008). The EIC initially operated an opium contract system, but accusations of corruption, abuse of locals and low quality products led to the adoption of an 'Agency System' in 1797 (Kranton and Swamy, 2008, 982). Private cultivation and sale was banned; agents provided capital advances to producers on behalf of the Company; farmers had to grow in specific areas, harvest and deliver opium to agents. It was then generally marked for auction in Calcutta to privateers, who would largely sell on to China (Kranton and Swamy, 2008). Profits were high, and monopoly power was openly wielded to thwart competition, and occasionally utilised to flood the market, such as during the $1830 \mathrm{os}$. Meanwhile, standards and quality maintained the Opium Agency and ensured it survived for over a century. By 186o, around the time the Crown ended the EIC and assumed direct administration of India, opium represented 17 per cent of the Government of India's revenues (Kranton and Swamy, 2008). Similar stories pervaded the region. In the last decades of the nineteenth century, the Netherlands' Indies opium farms accounted for 18 per cent of total colonial revenue, or 35 per cent of tax revenue, and French Cochin-China and Siam showed comparable figures (Trocki, 2002). In Siam in 1905-6, opium farms yielded one-fifth of total government revenue, almost double the second most important revenue source, gambling farms. Yet in 1907 the Siamese government abolished the opium farm system and took over sole administration of the opium monopoly (Brown, 1993).

As a counterexample, the EIC operated a typical procurement process for textiles - providing a capital or input advance with a promise to deliver by the supplier, whereupon compensation would be provided. This proved difficult to enforce given opportunities for both sides to partially go back on these commitments, and uncertain enforcement mechanisms. Competition amongst 
buyers gave weavers many potential outlets, linkages between the EIC and its local agents were weak and undermined by information asymmetries, and centralised EIC control in London limited the ability of local actors to adjust to market clearing prices (Kranton and Swamy, 2008). The EIC Opium Agency avoided many of these problems. It was a legal monopsony and monopoly, and thereby negated legal competition for suppliers' produce. Local agents had greater flexibility on pricing, while the EIC simultaneously pursued greater oversight of agents and reinvested supernormal profits into anti-corruption measures (Kranton and Swamy, 2008). Nevertheless, over time, the indigenous poppy growers of Yunnan and Sichuan provinces in China supplanted the role of traffickers and opium from British India. This meant that by the close of the nineteenth century, Qing China, specifically its south-west provinces where enforcement capabilities were more limited, was the world's largest producer of opium (Bello, 2003).

Burma, meanwhile, proved a complicated case. Ethnic divisions produced differing policies. Nineteenth century rulers in Burma had sought to prohibit opium use by ethnic Burmans, but largely excluded Chinese, Shan and Kachin inhabitants from restrictions on consumption. Initially, British conquest brought a standardisation of policies with India, including prohibitions on local production and mandating purchases of Indian monopoly opium. However, following the conquest of Upper Burma in 1885, a more strict policy was instituted, effectively mimicking the regulations imposed by previous Burmese rulers, forbidding the sale of alcohol or opium to Burmans, while establishing shops to sell to Chinese and non-Burmans (Richards, 2002b). Eventually, reformist pressure at home forced an application of these more stringent rules to Lower Burma also (Richards, 2002b). Thereby, within Burma, the Government of India had shifted from a pragmatic policy of what Richards terms 'maximum revenue from minimum consumption' and now 'committed itself to a new level of social control - one that would be exceedingly difficult to enforce' (Richards, 2002b, 413 and 418). A surge in the illicit market drove the government to quickly backtrack. It relaxed restrictions on licensed shops in Lower Burma and these gradually expanded, supplied by Indian opium as well as seizures of Chinese and Shan State Illicit Opium.

\section{1 \\ Rethinking the Socioeconomic Impacts of the Sino-Indian Opium Trade}

Conventional analysis has portrayed the Sino-Indian opium trade in stark terms. It was an aggressively extractive imperial enterprise that impoverished and degraded all but investors in the metropole. As Alfred McCoy wrote, British India 'became Asia's first large-scale opium smuggler, forcibly supplying 
an unwilling China' (McCoy, 2003, 78). This conception represented conventional wisdom for much of the last century, with many improbably attributing impoverishment to the suppliers as well. A 2019 B BC article, for example, sought to remind audiences 'How Britain's opium trade impoverished Indians' (Biswas, 2019).

More recent historical analysis, however, does not seem to support the viewpoint that 'opium causes poverty'. Some scholars attribute the development of capitalism in Southeast Asia to the revenue farming system, of which opium was a key pillar. As Trocki writes,

Before the nineteenth century, it is no exaggeration to say that capitalism did not really exist in Southeast Asia [...] Even those who did produce for the global market rarely sold their goods into the market and they consumed even less from it. Many exchanges were ritualised and took place within relations of dependence. Despite centuries of commerce, there was no real middle class in any Southeast Asian society, nor was there any 'free' wage labour. There was no properly commercial forms of production, finance or banking and there were no systems of law that would have protected or regulated such enterprises. Rulers were arbitrary and absolute; wealth in itself could not effectively exist without the protection of the power elites.

TROCKI, 2OO2, 299

It was the European empires that brought capitalism and stitched the Southeast Asian economies into the global economic system. Opium, at least in part, enabled this. However, it was not solely a European creation. Instead, it was the Chinese who largely created the local capitalist institutions capable of interfacing with the global economy. Under these conditions, opium farming served as a key impetus and mechanism, serving also as likely the largest financial generator for emerging Chinese businesses. Opium farming conferred primacy of wealth and political power, making contract holders 'inevitably the richest and most powerful individuals in their communities', extracting massive rents while engaging in minimal day-to-day activities (Trocki, 2002, 299). This is not to say that these contract holders had a largely passive role. They were key intermediaries, coalescing financial resources and investors, and subsequently managing the resultant investments. The farms, thereby, served as major focal points for capital accumulation, and with it economic and political power. This reality leads Trocki to label the opium farms as 'the first and perhaps most effective means of accumulation in nineteenth-century Southeast Asia' (Trocki, 2002, pp. 299-300). Once the opium passed through the monthly auctions, it 
ceased to be a concern of the EIC and would change hands multiple times before ending up with one of the large Chinese exporting firms, which would ship it to Shanghai via Hong Kong or south China ports and their mainland wholesalers (Newman, 1989).

Richards, meanwhile, argues that the trade 'benefitted the Indian economy and some groups in society more broadly than is generally recognised' (Richards, 2002a, 152). Both its export value and quantity increased over the nineteenth century. Coupled with a high value-to-weight ratio, this meant that its large profit margins had strong direct and indirect impacts on the economy (Richards, 2002b). The 1878 Opium Act superseded provincial regulations and their inconsistent application, and gave the Government of India the sole right to regulate and control production through distribution and possession (Richards, 2002b). By the 188os it was still likely one of the highest value commodities in global trade routes, with roughly 5,400 metric tons departing from Calcutta and Bombay each year, producing 93.5 million rupees in government revenue (Richards, 2002b, 377). Simultaneously, the Opium Act served to further cement a process already underway, namely shrinking the geographic areas under cultivation (Richards, 2002b).

Nevertheless, reformist pressure grew in Britain for the outright abolition of the trade. A Royal Commission on Opium was appointed to examine the question. Its findings, however, ran directly counter to the claims of abolitionists. The Commission minimised the impact that the trade was having on social and political decay, while pointing to the substantial financial and economic impacts an end to the trade would impose on India. Furthermore, China simply stood ready to step into the Indian void. China was under no actual obligation by that point to accept Indian opium as the British Government had publicly relinquished a right of intervention (Richards, 2002b). Reformists lambasted the report as pushing an economic status quo and 'whitewashing' of the reality on the ground (Berridge, 1999; Richards, 2002b). This negative view of the Commission has permeated much historiography since, although more recent revisionist historiography has pushed back. As Richards writes in 2005 , to assume

[t]hat the Government of India somehow deceived the members of the Commission by a Potemkin village façade is also erroneous [...]The Royal Commission on opium was not a whitewash [...] Opinion in the Indian-owned English language and Indian language press strongly opposed prohibition [...] [meanwhile] a majority of the leaders of the fledgling Indian National Congress, while uneasy with the moral aspects of the opium trade $[\ldots]$ disapproved of the anti-opium agitation occurring 
in England and [...] saw the reform campaign as a form of cultural imperialism.

RICHARDS, 2002b, pp. 380-1

Richards goes further:

In their zeal to attack the iniquities of the opium traffic and the British imperial interests that supported and profited from it, the reformers sensationalised the presumed harm done to Indian consumers of opium and minimized the costs to India of ending the traffic. They ignored Indian sensitivities by denying any cultural and social value to the use of opium. The opium reformers were blinded by strongly ethnocentric biasesmore so than those British officials, physicians and others who actually lived in India.

RICHARDS, 2OO2b, 381

In many ways, the British rulers feared most the social unrest that could follow any attempts to interfere with local cultural sensibilities, economic activities or other political sensitivities. Since the 1857 revolt, they had assiduously avoided anything that could provoke local backlash, such as interfering with the opium system. As Richards writes,

[f]or opium, as for alcohol and cannabis (ganja), the Government of India avoided absolutist positions. It assumed that consumption of these substances would continue, that abstinence was a chimera and that the best the state could do would be to restrain these habits. The system that emerged in each major region of the subcontinent was sensitive to varying local conditions, cultural preferences and economic circumstances.

RICHARDS, 2OO2b, 409

This would be mirrored by the approach of British administrators in Burma half a century later. Still, proponents of the status quo faced a losing battle. Professional moralists and reformers only increased pressure and international regulations, at first bilateral, then multilateral.

\section{$4 \quad$ New Regimes}

The beginning of the end of the mercantilist opium systems came with the Anglo-Chinese Opium Agreements of 1907-14. Britain, often portrayed as a 
reluctant protagonist in the international control system, in fact helped inaugurate it through these far-reaching bilateral agreements. From its peak in the 1870s, opium had been supplanted by domestic Chinese opium by 1900. Still, it represented the Government of India's third largest source of revenue and China's biggest source of customs revenue as well as a major cash crop for millions of Indian peasant farmers. Opium also served as an important social and 'quasi-medical' outlet for large numbers of labourers throughout the region, a physical and mental escape from the daily toil of back-breaking work (Newman, 1989). While traditional historiography portrayed Britain and other imperial powers as pursuing naked economic self-interest in bucking reformist calls for international prohibitions, more recent work has drawn a more complex picture. Imperial powers were at once conflicted and ambivalent about opium's role within the economic systems and societies they managed, but ultimately reluctant to attempt grand experiments with social engineering, such as prohibition (Collins, 2015; McAllister, 2000; Mills, 2014; Newman, 1989).

Nevertheless, changing economic realities helped weaken the opposition to prohibitions. Transportation improvements reinforced the comparative attractiveness of producing bulkier and perishable commodities for global markets. Wheat, barley, sugar, tobacco and potatoes all pushed poppy out of fields (Newman, 1989). In Ghazipur, opium production succumbed to rice and oil seed production in the 188 os, opium ending the century at roughly half the production it had seen in 1875 . In other parts, famine and irrigation difficulties and labour shortages drove a decline in production (Newman, 1989). Meanwhile, in the midst of controversy over the Royal Commission on Opium and accusations that local officials had 'ruthlessly stage managed' the field visits, Indian opium departments proved unwilling to allow opium prices to rise. Cultivators fled en masse to other crops, never to return. This led Robert Neuman to describe the sympathetic stance of the Royal Commission as 'a pyrrhic victory from which the Government of India never recovered' (Newman, 1989, 530). These issues only served to reinforce the critical challenge posed by Chinese domestic cultivation (Richards, 2002a) alongside incipient competition from Persian and Turkish opium within the region (Newman, 1989).

International opinion only hardened further against opium in the interim. A chorus of progressive and missionary opinion in the United States (US) coalesced with a vocal domestic China lobby. The latter in particular, saw opium as a policy bridge to strengthening Sino-US commercial relations (Collins, 2015). Simultaneously, the US encountered its own opium dilemma through its occupation of the Philippines. Ultimately, the US adopted a policy of outright 
prohibition, despite the misgivings of its local administrators (Musto, 1999). Washington looked at the European monopolies not as a mechanism to control a complicated trade, but as an attempt to provide legitimacy to a large source for potential diversion into illicit supplies. The only regulation the US argued as sustainable was outright prohibition except for medical and scientific use. Although the European powers initially continued to push back against this aggressive approach, the tide was clearly working against them (Collins, 2015; Musto, 1999).

China meanwhile took pre-emptive action. It announced with an imperial edict in 1906 that 'foreign and native opium' would be eradicated within ten years (quoted in Newman, 1989, 531). Despite significant scepticism, and mixed implementation, the campaign proved surprisingly effective, in the short run at least. The domestic mood in China had turned strongly against opium. These Chinese domestic efforts rendered resistance from British and Indian elites seemingly more indefensible (Newman, 1989). The Government of India and their Chinese counterparts reached an agreement whereby India would reduce its exports of opium to China by ten per cent per year, resulting in a predicted cessation of the trade in 1917. This agreement, the first of the Anglo-Chinese Opium Agreements, was signed in December 1907 and came into force in January 1908 (Newman, 1989). Britain, quite justifiably, viewed itself as having made a major concession, at a significant cost to its imperial coffers. In most areas-particularly Bihar and Benares, where it constituted a monopoly - the agreement largely served to reinforce trends away from opium cultivation. These trends were driven by various push and pull factors already discussed. In the more complicated region of Malwa, reduction proved more difficult from legal, administrative and economic perspectives. As Newman writes,

The opium interests in Malwa faced difficulty if not ruin. Local merchants needed to sell their chests with a minimum of delay to the exporters in Bombay if they were to recoup their investment; moreover, many of them were holding substantial reserves of old opium which now seemed unlikely to find a market at all. If local merchants and moneylenders became bankrupt they would reduce the supply of credit to Malwa peasantry and hamper the process of crop substitution, which was already less advanced in Malwa than in northern India [...] the decline of the China trade endangered many of the princely economies [...] [while] [i]n the matter of agricultural diversification and development there was little beyond exhortation that the Government of India could do.

NEWMAN, 1989, pp. $537-8$ 
China meanwhile surpassed its targets, as provincial officials bought into the policy, ripped up local crops, closed dens and thereby sought to minimise foreign imports. This was simply reinforced by the economic turmoil within China's regions (Newman, 1989). These factors weighed on the next round of Anglo-Chinese opium negotiations, which began in mid-1910. This, instead of an agreement, took the form of a treaty, formalising a continued and more legalistic commitment to 10 per cent annual reductions. The compromise outcome was praised in London but raised the ire of communities in India and China. The former lamented that their 'opium revenues are now practically gone' leaving them 'in a nice financial mess', while Chinese anti-opium groups reacted angrily to concessions made to India (quoted in Newman, 1989, 551). The reality, however, was the formalisation of Britain's commitment to the eradication of the opium trade with China.

In the meantime, multilateralism took root. Under Article 6 of The Hague Opium Convention of 1912, states parties committed to the gradual 'suppression of the manufacture, the internal traffic in and the use of prepared opium in so far as the different conditions peculiar to each nation shall allow' (The Hague International Opium Convention, 1912, Paragraph 6). Going into force following the Versailles settlement of World War I, under the aegis of the League of Nations, the international drug control system sought to implement this goal. It did so, however, in a broadly uneven manner. Opium smoking continued in the East Indies, Malaya, the Unfederated Malay States, Brunei, Sarawak, Burma, India, Ceylon, North Borneo, Hong Kong, Indochina and Siam (Collins, 2017a). Many governments argued that opium consumption in many of these contexts represents a form of medical use, which could be termed 'quasi-medical' use (Collins, 2015). Furthermore, outright prohibitions were seen as potentially worsening local conditions. This included undermining gains made in regulating consumption via rationing and registration, control over what would otherwise become an illicit market, and the positive spillovers from driving the revenue from opium into government coffers rather than actors that might seek to use it to weaken governance in the territories in which they operated (Collins, 2017a).

The international regulatory system, meanwhile, continued to develop at the intersection of these Sino-US and European colonial visions (Collins, 2018). However, its practical impact was limited by the functional collapse of the Chinese state. From 1917, local military leaders encouraged cultivation to strengthen their financial base in the face of dwindling central government control (Taylor, 1969). Japan also increased its role in the Chinese opium economy, shifting towards self-sufficiency in opium production and then becoming a leading supplier of illicit narcotics into China through its Southern Manchuria enclave (Jennings, 1997). In 1932, the Manchukuo puppet regime established 
a government-run monopoly, going against the grain of League of Nations control efforts and buying from states perceived as rogue operators within the emerging control regime (Collins, $2017 \mathrm{~b}$ ). Many have ascribed conspiracy to Japan's efforts - a forceful 'narcotisation' of China in pursuit of imperialist goals. Indeed, the same accusations were levelled against Japan in its war with the US (Collins, 2015). Others have pointed to economic-structural determinants. Japan was, like so many protagonists in licit and illicit drug markets, merely following strategic and economic necessities dictated by local political economies. As Meyer and Parssinen write, '[w] hat looked like genocide and conspiracy at the highest levels' actually represented 'political compromise in pursuit of larger goals' (Meyer and Parssinen, 2002, 280). In reality, both Japanese and Chinese forces utilised the opium trade for local and national strategic ends (Collins, 2017b).

The 1930s in India saw an appropriation of prohibition policies. The period 1920-40 witnessed a rapid decline in domestic consumption. The Indian National Congress Party pursued policies of local prohibition from 1937, and looked towards prohibition throughout the nation (Brown, 2002). World War II placed a temporary hold on these efforts, but US pressure on Britain had produced a broad, although not uniform, commitment to end the practice of opium smoking in territories upon reoccupation (Collins, 2017a). Furthermore, after independence in 1947 the National Congress reinstituted its policy aim of prohibiting all production and consumption except for medical and scientific use. The government established a Narcotics Commission to assume control of all aspects of production and pricing. Over the following six years, consumption reportedly fell by 45 per cent, largely due to restricted production and increased price. In 1959, sale was completely prohibited, and oral consumption was prohibited except for registered consumers. The shift in policy has been described by one scholar as 'one of the world's most successful campaigns to limit the drug's cultivation and use' (Brown, 2002, 627).

Others offer a more critical appraisal. As Richards writes,

Opium offered a cash crop to perhaps two million of the most skilful cultivators in both northern British and western Princely India. When opium exports dwindled and eventually ended in 1935, the Indian economy lost an economic asset, just as it did when indigo, for example, ceased to be a viable cash crop.

RICHARDS, 2002b, 18 o

Burma, meanwhile, emerged as a key actor in its own right in international drug policy when it separated from India in 1937. It was now expected to adhere 
to the various international treaties, but with no clear sense that it held the capacity to do so. The 1923 Opium Order established an effective legal monopoly over supply, making Cis-Salween Sawbwas opium monopsonists and further limiting sale to consumers (Maule, 1992). However, implementation varied. For example, the Northern Shan States operated via monopoly auctions, policed by the monopoly owner. In the Trans-Salween Shan States, weak political control negated such an approach. Proximity to China and the unchecked production underway there was viewed as a key limiting factor. This only strengthened British resolve that any risk of social unrest was too high a price to pay for the uncertain promise of additional opium prohibitions (Maule, 1992). Security, governance and development came first, for officials in Burma at least (Collins, 2016).

In 1931 Burma officials had proposed a closed system of control, with licenced shops being supplied by Shan State opium and potentially exporting excesses to Siam, French Indochina and the Dutch East Indies. London and the Government of India quickly vetoed the idea, citing, among other issues, international obligations under the emerging League of Nations treaty system. A compromise arrangement saw a commitment from the Government of India to continue supplying Burma with cheap opium, coupled with a light touch approach to the fluid production and informal trading arrangements on the borders with Siam and China. With formal separation from India in 1937, the idea of utilising Shan opium became appealing once again (Maule, 1992). Burma received a significant mark-up reselling cost price Indian opium, producing roughly 5 oo per cent profit. Although opium had collapsed to around 1 per cent of India's government revenue by the 1930s, for Burma the loss of this supply provoked a more acute fiscal unease. Recognising this reality, London sought to redirect the international spotlight away from the situation in Burma, for example exempting the Shan States from new obligations agreed at the 1931 Bangkok opium conference (Maule, 1992). Beneath this protective approach was a concern that any increased reliance on Shan opium would come at the cost of increased leakages into the illicit market and would thereby draw new international attention. The issue was not so much political will as regulatory capacity, something the Burmese government lacked in these outer regions (Collins, 2017b).

British policies produced a de facto division of the country based on governance capabilities and a pluralistic approach to policy enforcement (Collins, 2017b). Burma gained independence in January 1948 and focused immediately on internal security and economic recovery and development. It adopted a strict policy of neutrality in the emerging Cold War; however, the US came to view it as a key potential domino for a communist takeover of the 
region as well as a potential 'back door' into China (Selth, 2010). The Communist takeover of China in 1949 saw the greatest historical influx of refugees into the mountains of Shan and Kachin States. These refugees settled without the permission of the Burmese government and included remnants of the Kuomintang (Кмт) army and local Yunnan militias. These groups quickly coalesced into guerilla forces in the 1950s, their bases providing security and governance infrastructure, which drew in civilian refugees seeking protection from the Burmese army and local ethnic militias (Chang, 2009). The prolonged economic crisis in Burma resulted in a shortage of consumers' goods, which in turn stimulated the cross border illicit trade, which in turn funded the militias through taxation. Some estimates placed the trade at 8 o per cent of Burma's total consumption, most of which came via Thailand and through the Shan State (Chang, 2009, 550).

\section{5}

\section{Decolonisation and the Emergence of the Golden Triangle}

The Golden Triangle would ultimately emerge at the intersection of these forces and geographic areas. It centres on the bordering regions of Burma, Laos and Thailand. It is a remote, densely forested area populated by a diverse array of ethnic groups, many of whom traditionally followed semi-nomadic slash-andburn agriculture practices (Chouvy, 2013). As Chouvy writes,

[T] he international borders of Burma, Laos, and Thailand also cut across two zones that are intricately woven together: the Tai linguistic zone, composed of Shan, Thai, and Lao peoples, over which is superimposed a more complex zone of numerous other ethnic groups that are dispersed throughout the tri-border area and in neighbouring China.

CHOUVY, 2013, 1

The region flourished as a postcolonial centre of the illicit trade for the same reasons it had proven so difficult to incorporate under colonial economic and political systems of control. It is based within untamed terrain of mountains, rivers and forest, with minimal infrastructure and a reality of annual monsoons that negate whatever infrastructure does exist for several months of the year. In such circumstances, the reliance on cash crops becomes not only explicable but often essential to community survival. Much like the earlier evolutions of the opium trade within the region, however, these geographic and ethnic determinants were not sufficient explainers for the emergence of the Golden Triangle. The political economy of the post-war region was also a key determining 
factor. Evaluating the economic and developmental overlaps between the colonial and postcolonial periods, however, is the focus of another paper.

\section{$6 \quad$ Conclusion}

This paper demonstrates that the linkage between drugs and development is a longer historical phenomenon. While contemporary discourses rightly seek to carve greater space for development criteria within drug policy debates, this need is driven by a more recent systemic approach to drugs that has viewed its policy goals and outcomes in terms of repression, market reduction and an ever-greater reliance on prohibition (Collins, 2016). Development practitioners highlight that the most recent international drug control treaty, the $1988 \mathrm{UN}$ Convention Against Illicit Traffic in Narcotic Drugs and Psychotropic Substances, references the role of development, but in subservience to eradication efforts. Development could serve as a mechanism to achieve drug control goals, but has not been seen as an end in itself (Brombacher and Westerbarkei, 2019). This chapter has sought to highlight the historical counter-narratives to this prohibitionist mindset that captured UN discourses following the Second World War.

Drug economies have been inextricably tied to processes of globalisation, economic development and governance over the past several centuries at least. Drug economies were often central to economic development, rather than something parallel or running counter to mainstream state consolidation efforts. Policymakers frequently viewed the issue through economic and political lenses and formulated complex policy responses based on a mix of regulatory and prohibitionist elements. The drive towards prohibition as a sole global policy goal began to slowly coalesce around the turn of the twentieth century, but was far from an inevitability or a natural policy goal. Administrators and local populations throughout Asia had a more complex interplay with these local, regional and international drug economies than is often recognised. Although the Royal Commission was accused of an amoral 'whitewashing' of the Sino-Indian opium trade in the region, the reality is just as likely that moralisers and subsequent internationalists and prohibitionists were equally, if not more, guilty of whitewashing the complexity of the socio-economic-political linkages between drug economies and societies in Asia. The recentring of the Sino-Indian opium trade into the Golden Triangle attests to the reality of drugs and drug economies as complex economic and development phenomena, eschewing dichotomous labels of 'licit' and 'illicit', or dichotomous policy frameworks of 'regulation' and 'prohibition'. Recognising these realities and re-examining the historical complexity of regulations within Asia is therefore 
likely a good starting point for a better understanding of the linkages between drug economies and economic development.

\section{References}

Bassi, A., L. Casier, D. Laborde, M. Linsen, D. Manley, N. Maennling, H. Mann, M. Siersted, C. Smaller, I. Steel, D. Uzsoki and J. West (2019) Modelling for Sustainable Development: New decisions for a new age (Winnipeg: IISD, International Institute for Sustainable Development).

Bello, D. (2003) 'The Venomous Course of Southwestern Opium: Qing Prohibition in Yunnan, Sichuan, and Guizhou in the Early Nineteenth Century', Journal of Asian Studies, 62, pp. 1109-1142, DoI: 10.2307/3591761.

Berridge, V. (1999) Opium and the People: Opiate Use and Drug Control Policy in Nineteenth and Early Twentieth Century England (London: Free Association Books).

Biswas, S. (2019) 'How Britain's opium trade impoverished Indians', BBC News, https:// www.bbc.com/news/world-asia-india-49404024 (accessed on 20 April 2020).

Brombacher, D. and J. Westerbarkei (2019) 'From Alternative Development to Sustainable Development: The Role of Development Within the Global Drug Control Regime', Journal of Illicit Economies and Development, 1(1), pp.89-98, DoI: 10.31389/ jied.12.

Brown, I. (1993) 'The End of the Opium Farm in Siam, 1905-7', in J. Butcher and H. Dick (eds), The Rise and Fall of Revenue Farming: Business Elites and the Emergence of the Modern State in Southeast Asia, Studies in the Economies of East and South-East Asia (London: Palgrave Macmillan), pp. 233-245, DoI: 10.1007/978-1-349-22877-5_13.

Brown, R.H. (2002) 'The Opium Trade and Opium Policies in India, China, Britain, and the United States: Historical Comparisons and Theoretical Interpretationism', Asian Journal of Social Science, 30, pp. 623-656, D oI: 10.1163/156853102320945420.

Buxton, J. (2015) Drugs and development: The great disconnect (Swansea: Global Drug Policy Observatory), https://www.swansea.ac.uk/media/Drugs-and-DevelopmentThe-Great-Disconnect.pdf (accessed on 20 April 2020).

Chang, W. (2009) 'Venturing into "Barbarous" Regions: Transborder Trade among Migrant Yunnanese between Thailand and Burma, 196os-198os', Journal of Asian Studies, 68, pp. 543-572, DoI: 10.1017/Soo21911809000709.

Chouvy, P.-A. (2013) 'Drug trafficking in and out of the Golden Triangle', in: An Atlas of Trafficking in Southeast Asia. The Illegal Trade in Arms, Drugs, People, Counterfeit Goods and Natural Resources in Mainland (London: IB Tauris), pp. 1-32.

Collins, J. (2018) 'Rethinking "flexibilities" in the international drug control systemPotential, precedents and models for reforms', International Journal of Drug Policy, 6o, pp. 107-114, DOI: 10.1016/j.drugpo.2016.12.014. 
Collins, J. (2017a) 'Breaking the Monopoly System: American influence on the British decision to prohibit opium smoking and end its Asian monopolies, 1939-1945', The International History Review, 39(5), pp.770-79o, Do I:10.1080/07075332.2017.1280519.

Collins, J. (2017b) 'War, Decolonisation and The Birth of the Illicit Opium Trade in Burma', in J. Windle, J. Mirrison, A. Winter and A. Silke (eds), Historical Perspectives on Organised Crime and Terrorism (Abingdon-on-Thames : Routledge).

Collins, J. (2016) 'Development First: Multilateralism in the Post-“War on Drugs" ' Era', in J. Collins and A. Soderholm (eds) After the Drug Wars: Report of the LSE Expert Group on the Economics of Drug Policy, (London: London School of Economics and Political Science, LSE).

Collins, J. (2015) Regulations and prohibitions: Anglo-American relations and international drug control, 1939-1964 (London: LSE).

Courtwright, D. (2012) 'A Short History of Drug Policy or Why We Make War on Some Drugs but not on Others', in J. Collins (ed.) Governing the Global Drug Wars (London: LSE IDEAS).

Jennings, J.M. (1997) The Opium Empire: Japanese Imperialism and Drug Trafficking in Asia, 1895-1945 (Westport, Conn: Praeger).

Kranton, R. and A.V. Swamy (2008) 'Contracts, Hold-Up, and Exports: Textiles and Opium in Colonial India', American Economic Review, 98(3), pp. 967-99o, DoI: 1257/ aer.98.3.967.

League of Nations (1930) The Problem of Prepared Opium, C.635.H.254.1930.XI, November 1930, Vol. I (Geneva: League of Nations).

Mansfield, D. and A. Pain (2005) Alternative Livelihoods: Substance or Slogan?, Briefing Paper (Kabul: Afghan Research and Evaluation Unit), https://areu.org.af/publication/524/ (accessed on 20 April 2020).

Maule, R. (1992) 'The Opium Question in the Federated Shan States, 1931-36: British Policy Discussions and Scandal', Journal of Southeast Asian Studies, 23, pp. 14-36.

McAllister, W.B. (200o) Drug Diplomacy in the Twentieth Century: an International History (New York: Routledge).

McCoy, A.W. (2003) The Politics of Heroin: CIA Complicity in the Global Drug Trade, Afghanistan, Southeast Asia, Central America, Colombia, 3rd ed. (New York: Lawrence Hill Books).

Meyer, K. and T.M. Parssinen (2002) Webs of Smoke: Smugglers, Warlords, Spies, and the History of the International Drug Trade (Oxford: Rowman \& Littlefield).

Mills, J.H. (2014) 'Cocaine and the British Empire: The Drug and the Diplomats at the Hague Opium Conference, 1911-12', The Journal of Imperial and Commonwealth History, 42(3), pp. 400-419, DOI: 10.1080/03086534.2014.894701.

Musto, D.F. (1999) The American Disease: Origins of Narcotic Control, 3rd ed. (London: Oxford University Press). 
Newman, R.K. (1989) 'India and the Anglo-Chinese Opium Agreements, 1907-14', Modern Asian Studies 23(3), pp. 525-56o.

Richards, J.F. (2002a) 'The opium industry in British India', The Indian Economic and Social History Review, 39(2-3), pp. 149-180, Dor: 10.1177/oo1946460203900203.

Richards, J.F. (2002b) 'Opium and the British Indian Empire: The Royal Commission of 1895', Modern Asian Studies, 36, pp. 375-420, DoI: 10.1017/Soo26749X02002044.

Scott, P.D. (2010) American War Machine: Deep Politics, the CIA Global Drug Connection, and the Road to Afghanistan (Lanham: Rowman \& Littlefield Publishers).

Selth, A. (2010) 'Modern Burma Studies: A Survey of the Field', Modern Asian Studies, 44, pp. 401-440.

Spillane, J. and W.B. McAllister (2003) 'Keeping the lid on: a century of drug regulation and control', Drug Alcohol Depend, 70, pp. S5-S12, Dor: 10.1016/So3768716(o3)ooog6-6.

Taylor, A.H. (1969) American Diplomacy and the Narcotics Traffic, 1900-1939: A Study in International Humanitarian Reform (Durham: Duke University Press).

The Hague International Opium Convention (1912) The Hague.

Trocki, C.A. (2002) 'Opium and the Beginnings of Chinese Capitalism in Southeast Asia., Journal of Southeast Asian Studies, 33(2), pp. 297-314, DoI: 10.1017/ Soo22463402000152.

Trocki, C.A. (1999) Opium, Empire and the Global Political Economy: A Study of the Asian Opium Trade, 1750-1950 (New York: Routledge).

UN General Assembly (2016) Our joint commitment to effectively addressing and countering the world drug problem, A/RES/S-30/1, (New York: United Nations).

UN General Assembly (2015) Transforming our World: the 2030 Agenda for Sustainable Development, A/RES/70/1, (New York: United Nations), https://sustainabledevelopment.un.org/post2015/transformingourworld (accessed on 20 April 2020).

UN General Assembly (2013) United Nations Guiding Principles on Alternative Development, A/RES/68/196, (New York: United Nations).

Walker, W.O. (1992) 'Drug Trafficking in Asia', Journal of Interamerican Studies and World Affairs, 34, pp. 201-216, DOI: 10.2307/165928.

Westad, O.A. (2012) Restless Empire: China and the World Since 1750 (London: The Bodley Head).

Windle, J. (2012) 'Insights for Contemporary Drug Policy: A Historical Account of Opium Control in India and Pakistan', Asian Journal of Criminology, 7(1), pp. 55-74, DOI: 10.1007/s11417-011-9104-o. 